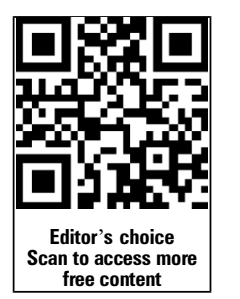

${ }^{1}$ Department of Internal Medicine, Diabetes Center, VU University Medical Center, Amsterdam, The Netherlands ${ }^{2}$ Department of Gastroenterology and Hepatology, Erasmus University Medical Center, Rotterdam, The Netherlands

\section{Correspondence to} Dr Mark Smits, Department of Internal Medicine, Diabetes

Center, VU University Medical Center, De Boelelaan 1117.

Amsterdam $1081 \mathrm{HV}$,

The Netherlands;

mm.smits1@vumc.nl

Received 17 August 2015 Revised 22 December 2015 Accepted 23 December 2015 Published Online First 19 January 2016

\begin{tabular}{l}
\hline To cite: Smits MM, van \\
Raalte DH, Tonneijck L, \\
et al. Gut 2016;65: \\
702-711. \\
\hline
\end{tabular}

\title{
GLP-1 based therapies: clinical implications for gastroenterologists
}

\author{
Mark M Smits, ${ }^{1}$ Daniel H van Raalte, ${ }^{1}$ Lennart Tonneijck, ${ }^{1}$ Marcel H A Muskiet, ${ }^{1}$ \\ Mark H H Kramer, ${ }^{1}$ Djuna L Cahen ${ }^{2}$
}

\section{ABSTRACT}

The gut-derived incretin hormone, glucagon-like peptide 1 (GLP-1) lowers postprandial blood glucose levels by stimulating insulin and inhibiting glucagon secretion. Two novel antihyperglycaemic drug classes augment these effects; GLP-1 receptor agonists and inhibitors of the GLP-1 degrading enzyme dipeptidyl peptidase 4. These so called GLP-1 based or incretin based drugs are increasingly used to treat type 2 diabetes, because of a low risk of hypoglycaemia and favourable effect on body weight, blood pressure and lipid profiles. Besides glucose control, GLP-1 functions as an enterogastrone, causing a wide range of $\mathrm{Gl}$ responses. Studies have shown that endogenous GLP-1 and its derived therapies slow down digestion by affecting the stomach, intestines, exocrine pancreas, gallbladder and liver. Understanding the Gl actions of GLP-1 based therapies is clinically relevant; because $\mathrm{Gl}$ side effects are common and need to be recognised, and because these drugs may be used to treat $\mathrm{Gl}$ disease.

\section{INTRODUCTION}

The incretin hormone glucagon-like peptide 1 (GLP-1) is secreted by the gut in response to nutrient ingestion. It enhances insulin secretion by the pancreatic islet cells and inhibits glucagon secretion, thereby lowering postprandial blood glucose levels. ${ }^{1}$ Two novel drug classes were developed to augment these responses and target hyperglycaemia in type 2 diabetes (T2DM): GLP-1 receptor agonists (GLP-1RAs) and inhibitors of the GLP-1 degrading enzyme, dipeptidyl peptidase 4 inhibitors (DPP-4Is) (table 1). Based on their pharmacokinetic profiles, GLP-1RAs are classified into short-acting and long-acting agents. At present, these GLP-1 (or incretin) based drugs are widely used as second-line treatment for T2DM, after metformin has failed. ${ }^{2}$

Apart from contributing to the enteroinsular axis, GLP-1 is involved in several other processes. Thus, GLP-1 based therapies have extrapancreatic effects including early satiety, weight loss, increased insulin sensitivity, blood pressure lowering and improved lipid profiles. ${ }^{3}$ These actions have been extensively advocated, because of potential cardiovascular benefits. Less attention has been given to the GI effects of GLP-1 and associated therapies. By delaying a range of digestive processes, these responses contribute to glucose lowering. ${ }^{4}$ Endogenous GLP-1 reduces proximal GI motility, whereas pharmacological concentrations influence the physiology of the stomach, intestines, exocrine pancreas, gallbladder and liver.

Understanding the GI effects of these drugs is of clinical importance. First, GLP-1 based drugs may be employed to treat GI disorders, as emerging evidence indicates that they are beneficial in, for instance, non-alcoholic fatty liver disease (NAFLD), IBS and short bowel syndrome. Second, they often cause GI complaints, mostly nausea, constipation and diarrhoea. With their increasing prescription rate, such side effects will be frequently encountered and need to be recognised. Finally, concerns have been raised that GLP-1 based therapies may induce pancreatitis and pancreatic cancer.

In order to understand the GI implications of GLP-1 based therapies, it is necessary to return to the physiological basis. This review will provide insight in the underlying mechanisms of GLP-1 and GLP-1 based therapies and discusses the potential beneficial and adverse effects of these new drugs on each GI organ system.

\section{GLP-1 PHYSIOLOGY}

As the name suggests, GLP-1 is homologous to glucagon, sharing the precursor proglucagon. Alternate splicing leads to glucagon production in the pancreatic $\alpha$-cells and GLP-1 in the enteroendocrine L cells. ${ }^{5} \mathrm{~L}$ cells are present throughout the intestine, but predominantly in the distal ileum. These cells are triggered to secrete GLP- 1 by the presence of nutrients (mostly glucose and fat), as well as by bile acids (figure 1) ${ }^{6-8}$ Already minutes after a meal, plasma GLP-1 levels start to rise, peaking after $2 \mathrm{~h}$. Since GLP-1 secretion starts prior to the arrival of nutrients to the ileum, a feed-forward loop must be present. This indirect mechanism seems to involve neuronal pathways. For instance, blockage of the acetylcholine receptor of $\mathrm{L}$ cells by atropine inhibits this early GLP-1 secretion in humans. ${ }^{9}$

The actions of GLP-1 are thought to be effectuated by the GLP-1 receptor (GLP-1R), which is present in numerous organs (figure 2). ${ }^{10}{ }^{11}$ However, when this receptor is antagonised by exendin (9-39), some effects still pertain, suggesting involvement of additional receptors. ${ }^{12}$ After meals, GLP-1 levels quickly return to baseline. Rapid degradation by dipeptidyl peptidase 4 (DPP-4) and renal clearance of GLP-1 and its metabolites result in a half-life of $1-2$ min. ${ }^{13}{ }^{14}$ Only $10-15 \%$ of the endogenous GLP-1 enters the circulation (figure 1). ${ }^{15}$ Given this low systemic concentration, indirect receptor stimulation through the vagal nerve was postulated. Indeed, in animals and humans, vagal blocking diminished the effects of GLP-1. ${ }^{16} 17$

\section{Incretin and enterogastrone}

Endogenous GLP-1 stimulates pancreatic insulin secretion in a glucose-dependent manner. As such, 
Table 1 Overview of the registered GLP-1 receptor agonists and DPP-4 inhibitors

\begin{tabular}{|c|c|c|c|c|c|}
\hline Agent & $\begin{array}{l}\text { Brand } \\
\text { name }\end{array}$ & Dose & $\begin{array}{l}\text { Half-life } \\
\text { (h) }\end{array}$ & Elimination & $\begin{array}{l}\text { Renal } \\
\text { insufficiency* }\end{array}$ \\
\hline \multicolumn{6}{|l|}{ GLP-1 receptor agonists } \\
\hline \multicolumn{6}{|l|}{ Short-acting } \\
\hline Exenatide twice daily & Byetta & Subcutaneous 5-10 $\mu \mathrm{g}$ BID & 2.4 & Renal, proteolytic degradation & $\begin{array}{l}\text { Moderate: caution } \\
\text { Severe: NR }\end{array}$ \\
\hline Lixisenatide & Lyxumia & Subcutaneous $10 \mu \mathrm{g}$ once daily & 3.0 & Renal, metabolic degradation & $\begin{array}{l}\text { Moderate: caution } \\
\text { Severe: NR }\end{array}$ \\
\hline \multicolumn{6}{|l|}{ Long-acting } \\
\hline Albiglutide & $\begin{array}{l}\text { Eperzan } \\
\text { Tanzeum }\end{array}$ & Subcutaneous $30-50 \mathrm{mg}$ once weekly & $86.4-163.2$ & Proteolytic degradation & NR \\
\hline Dulaglutide & Trulicity & Subcutaneous $0.75-1.5 \mathrm{mg}$ once weekly & 112 & Proteolytic degradation & $\begin{array}{l}\text { Moderate: caution } \\
\text { Severe: NR }\end{array}$ \\
\hline Exenatide once weekly & Bydureon & Subcutaneous 2 mg once weekly & $2.4 \dagger$ & Renal, proteolytic degradation & NR \\
\hline Liraglutide & Victoza & Subcutaneous $1.2-1.8 \mathrm{mg}$ once daily & 13.0 & $\begin{array}{l}\text { Generalised proteolysis; Elimination: renal } \\
(6 \%) \text {; faecal }(5 \%)\end{array}$ & $\begin{array}{l}\text { Moderate: caution } \\
\text { Severe: NR }\end{array}$ \\
\hline \multicolumn{6}{|l|}{ DPP-4 inhibitors } \\
\hline Alogliptin & $\begin{array}{l}\text { Nesina } \\
\text { Vipidia }\end{array}$ & Oral $25 \mathrm{mg}$ once daily & $12.5-21.1$ & Renal (>70\% unchanged) & Dose reduction \\
\hline Linagliptin & Trajenta & Oral 5 mg once daily & $10.0-40.0$ & Renal (5\%); faecal (95\%) & No adjustment \\
\hline Saxagliptin & Onglyza & Oral $5 \mathrm{mg}$ once daily & $2.2-3.8$ & $\begin{array}{l}\text { Metabolised to active metabolite, renal } \\
\text { elimination (12-29\% unchanged, } 21-52 \% \\
\text { metabolite) }\end{array}$ & Dose reduction \\
\hline Sitagliptin & Januvia & Oral $100 \mathrm{mg}$ once daily & $8.0-24.0$ & Renal (80\% unchanged) & Dose reduction \\
\hline Vildagliptin & $\begin{array}{l}\text { Galvus } \\
\text { Zomelis } \\
\text { Jalra }\end{array}$ & $\begin{array}{l}\text { Oral } 50 \mathrm{mg} \text { twice daily (or } 50 \mathrm{mg} \text { once daily } \\
\text { plus sulfonylurea) }\end{array}$ & $1.5-4.5$ & $\begin{array}{l}\text { Metabolised to inactive metabolite, renal } \\
\text { excretion ( } 22 \% \text { unchanged) }\end{array}$ & Dose reduction \\
\hline
\end{tabular}

it is involved in the so called 'incretin effect', meaning higher insulin release after oral glucose intake, than after intravenous glucose administration. Its potency is demonstrated by blockage of the GLP-1R, which results in a $50-70 \%$ decrease in insulin secretion after oral glucose intake. ${ }^{18-20}$ In addition, GLP-1 may also serve as an enterogastrone, a hormonal mediator of the ileal brake phenomenon. ${ }^{21}$ This mechanism guards the distal intestine from caloric overload, by reducing GI transit, gastric acid secretion, pancreatic exocrine excretion and gallbladder emptying. ${ }^{22}$ Several studies using the GLP-1 receptor antagonist exendin (9-39) revealed an inhibitory role of GLP-1 on proximal GI motility. ${ }^{20}$ 23-25 Some even suggest that the role of GLP-1 as enterogastrone outweighs its role as incretin in glucose homoeostasis. ${ }^{26} 27$

\section{GLP-1 BASED MEDICATION}

GLP-1 based drugs mimic and exceed the effects of endogenous GLP-1 on metabolism and digestion, causing additional changes in intestinal mucosal proliferation, gallbladder motility, and hepatic glucose and lipid production (figure 2). ${ }^{28}$ Two types of GLP-1 based therapies are in use: incretin mimetics; GLP-1RAs that bind to the GLP-1 receptor and mimic the action of GLP-1, and incretin enhancers; DPP-4Is that prolong endogenously produced GLP-1 activity, and the activity of other hormones that are degraded by DPP-4 (table 2).

For both antihyperglycaemic drug classes, several agents have been approved for the treatment of T2DM. The first available GLP-1RA, exenatide, was based on a peptide extracted from saliva of the gila monster (Heloderma suspectum). Subsequently,

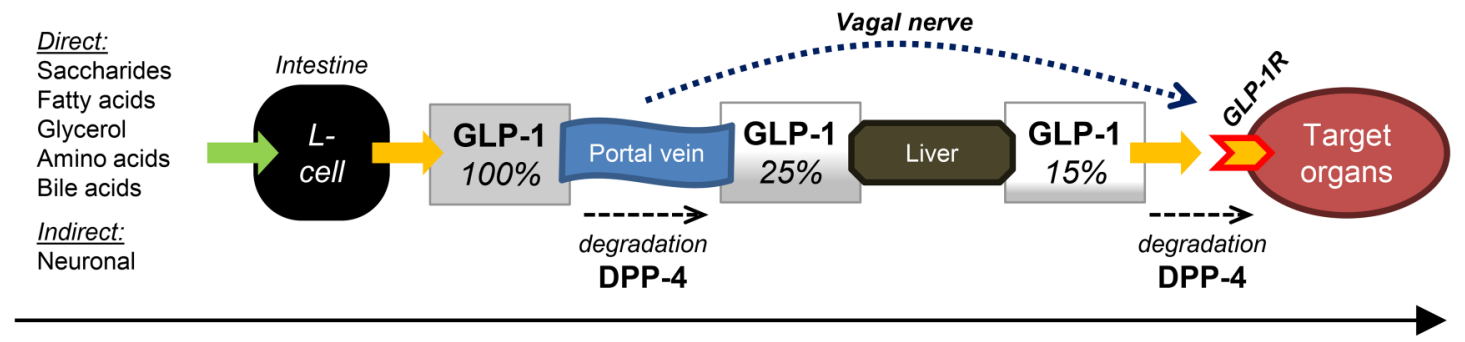

Figure 1 GLP-1 life cycle. Legend: GLP-1 is secreted from intestinal L cells after direct stimulation of luminal receptors or indirect stimulation through neuronal pathways. As soon as GLP-1 is released in the portal circulation, degradation by DPP-4 occurs. When GLP-1 reaches the liver, $25 \%$ of the originally secreted GLP-1 is left. Further degradation occurs in the liver and arterial system, and only 15\% reaches peripheral organs. Here, GLP-1 stimulates the GLP-1 receptor. GLP-1 additionally affects target organs through indirect stimulation of the vagal nerve in the portal vein. DPP-4, dipeptidyl peptidase 4; GLP-1, glucagon-like peptide 1; GLP-1R; glucagon-like peptide 1 receptor. 


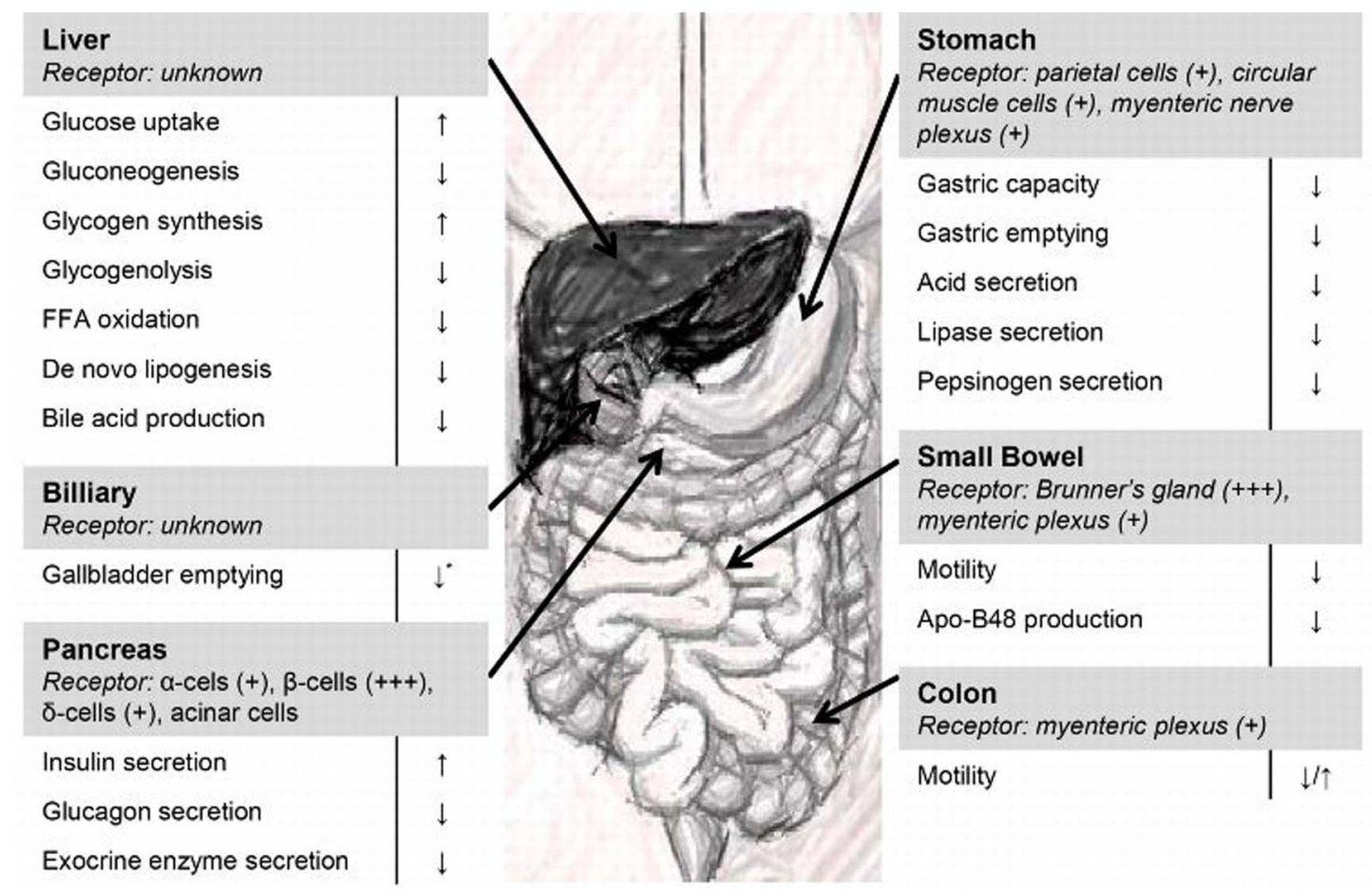

Figure 2 The effects of GLP-1 on different GI organ systems. Legend: Receptor concentrations are graded from (+) to (+++) and were determined using validated immunohistochemistry or autoradiography methods. ${ }^{10} 11$ *effects have only been demonstrated for GLP-1RA, effects of GLP-1 peptide unstudied. Apo-B48, apolipoprotein B48; FFA, free fatty acid; GLP-1, glucagon-like peptide 1.

synthetic forms, more homologous to human GLP-1, were developed. The crucial difference between endogenous GLP-1 and GLP-1RAs is the susceptibility for degradation by DPP-4. GLP-1RAs are resistant to degradation, leading to prolonged half-lives of $2-160 \mathrm{~h}$. Combined with a high dose administration, this results in 6-10 times supranatural serum levels. ${ }^{29}$ Based on their half-lives, GLP-1RAs are classified as short-acting agents (exenatide twice daily and lixisenatide) and long-acting agents (albiglutide, dulaglutide, exenatide once weekly and liraglutide). GLP-1RAs are administered subcutaneously, ranging from twice daily to once weekly, but other routes are being investigated. $^{30}$

DPP-4Is are taken orally, once or twice daily, while onceweekly formulations are currently being developed. ${ }^{31}$ They inhibit degradation by $80-97 \%$, with half-lives of $2-40 \mathrm{~h}$ and maintain GLP-1 at postprandial levels. ${ }^{29}$ However, DPP-4 degrades GLP-1, and several other hormones, including glucosedependent insulinotropic peptide, glucagon-like peptide 2 (GLP-2) and peptide YY (PYY) (table 2). Hence, DPP-4Is have a wider range of actions than GLP-1RAs. Because some of these actions neutralise each other, GI effects are more pronounced with GLP-1RAs than DPP-4Is.

\section{GI EFFECTS OF GLP-1 BASED THERAPIES}

\section{Stomach and duodenum}

GLP-1 and GLP-1RAs decrease gastric emptying in healthy volunteers and patients with diabetes. ${ }^{32}$ In a variety of studies, GLP-1 prolongs the lag time, inhibits propulsion waves, stimulates pyloric tone and doubles time to empty $50 \%$ of gastric contents. $^{32-37}$ It also decreases gastric acid and lipase secretion by $67 \%$ and $36 \%$, respectively. ${ }^{38} 39$ The underlying mechanisms for these responses are unclear. Direct stimulation of GI smooth muscle cells by GLP-1 did not change gastric tone in rats. ${ }^{40}$ After vagal blocking, the GLP-1 effect on gastric motility was lost. ${ }^{16} 1725$ Combined, these data suggest vagal mediation.
While short-acting agents retain their gastric inhibitory effects after prolonged treatment, these effects wane significantly with long-acting GLP-1RAs, already after 2 weeks. ${ }^{41-43}$ Tachyphylaxis, due to sustained receptor exposure by longacting agents, has been postulated to cause this phenomenon. However, this theory is mostly based on small studies in healthy volunteers. 4445

In contrast to GLP-1RAs, DPP-4Is have little to no effect on gastric motility. ${ }^{24} 324647$ An explanation for this discrepancy remains elusive. Some have speculated that the DPP-4I-induced rise in GLP-1 to postprandial levels is not high enough to cause gastric inhibition, ${ }^{48}$ but GLP-1 infusion up to similar levels did reduce gastric emptying. ${ }^{49}$ An alternative hypothesis is that DPP-4Is simultaneously affect other peptides that counteract the inhibitory effect of GLP-1. For example, degradation of PYY (1$36)$ to the more potent gastric inhibitor PYY (3-36) is prevented by DPP-4 inhibition. ${ }^{50}$

\section{Clinical implications \\ Glucose control}

A complex interaction exists between glycaemia and gastric motility. ${ }^{51}$ Higher glucose levels delay, whereas lower levels stimulate gastric emptying. ${ }^{52-54}$ As a result, the inhibitory effect of GLP-1 on gastric emptying is more pronounced during hyperglycaemia and reduced during hypoglycaemia. ${ }^{52} 53$ Conversely, gastric emptying rate is accountable for approximately $35 \%$ of the postprandial glucose excursions. ${ }^{55} \quad 56$ Consequently, inhibition of gastric emptying by GLP-1 and short-acting GLP-1RAs reduces postprandial glucose levels. ${ }^{34} 57$ The significance of this effect was demonstrated in a study where co-infusion of the prokinetic erythromycin blunted the inhibiting effect of GLP-1 infusion on postprandial glucose excursions. $^{58}$ 
Table 2 Other peptides degraded by DPP-4 and their actions, stimulated during DPP-4 inhibition

\begin{tabular}{|c|c|}
\hline Peptide & Actions \\
\hline PYY (1-36) & $\begin{array}{l}\text { Gastric acid secretion } \downarrow \\
\text { Gastric emptying } \downarrow \\
\text { Gl transit } \downarrow \\
\text { Electrolyte/water secretion } \downarrow \\
\text { Pancreatic exocrine secretion } \downarrow \\
\text { Gallbladder contraction } \downarrow\end{array}$ \\
\hline NPY (1-36) & $\begin{array}{l}\text { GI motility } \downarrow \\
\text { Electrolyte/water secretion } \downarrow \\
\text { Intestinal inflammation } \uparrow\end{array}$ \\
\hline GLP-2 (1-33) & $\begin{array}{l}\text { Gastric acid secretion } \downarrow \\
\text { Intestinal mucosa growth } \uparrow \\
\text { Nutrient absorption } \uparrow \\
\text { Intestinal blood flow } \uparrow \\
\text { Gl transit } \downarrow\end{array}$ \\
\hline GIP (1-42) & $\begin{array}{l}\text { Intestinal glucose uptake } \uparrow \\
\text { GI transit } \downarrow\end{array}$ \\
\hline VIP & $\begin{array}{l}\text { Gastric acid secretion } \downarrow \\
\text { Electrolyte/water secretion } \downarrow \\
\text { Nutrient absorption } \downarrow \\
\text { Bicarbonate secretion } \uparrow \\
\text { Gl transit } \uparrow \\
\text { Gallbladder contraction } \downarrow\end{array}$ \\
\hline Bradykinin & $\begin{array}{l}\text { Nociception/pain } \uparrow \\
\text { Hepatic gluconeogenesis } \downarrow \\
\text { Gallbladder contraction } \uparrow\end{array}$ \\
\hline SP & $\begin{array}{l}\text { GI transit } \uparrow \\
\text { Intestinal chloride secretion } \uparrow \\
\text { Intestinal inflammation } \uparrow\end{array}$ \\
\hline Prolactin & Gastric emptying $\downarrow\left(\delta^{\curvearrowright}\right) / \uparrow($ (ᄋ) \\
\hline Endomorphin-2 & GI transit $\downarrow$ \\
\hline GRP & Gastrin release $\uparrow$ \\
\hline Interleukin 2 & Intestinal chloride secretion $\uparrow$ \\
\hline CLIP & Amylase release $\uparrow$ \\
\hline \multicolumn{2}{|c|}{$\begin{array}{l}\text { In addition to GLP-1, DPP-4 cleaves a number of other peptides and hormones. } \\
\text { Therefore, inhibition of DPP-4 also leads to altered levels and activity of these } \\
\text { substrates. Whether these effects, which were mainly demonstrated in preclinical } \\
\text { models, have a role in patients remains to be demonstrated. } \\
\text { CLIP, corticotropin-like intermediate lobe peptide; GIP, glucose-dependent } \\
\text { insulinotropic peptide; GLP-2, glucagon-like peptide 2; GRP, gastrin-releasing peptide; } \\
\text { NPY, neuropeptide Y; PYY, peptide YY; SP, substance P; VIP, vasoactive intestinal } \\
\text { peptide. }\end{array}$} \\
\hline
\end{tabular}

\section{Weight loss}

While DPP-4Is are weight-neutral, GLP-1RAs (short-acting and long-acting) induce weight loss in a dose-dependent manner. ${ }^{59}$ Recently, a high-dose preparation of the long-acting GLP-1RA liraglutide $(3.0 \mathrm{mg})$ has been approved for weight reduction. ${ }^{60}$ Mechanisms underlying this weight loss are still incompletely understood. A GLP-1RA-mediated reduction in gastric emptying was postulated to be responsible for decreased appetite. However, the waning effect of tachyphylaxis and reduced fasting appetite suggest other, additional mechanisms. ${ }^{61}$ Likely, central neurological mechanisms are involved. Preclinical data show that GLP-1 reduces homeostatic and reward-associated food intake and, in humans, GLP-1 affects brain areas related to feeding and satiety. ${ }^{62}$ Yet, in a recent study, liraglutide reduced central nervous activation initially, but no longer after 12 weeks of treatment, while self-reported hunger scores remained suppressed. ${ }^{63}$ Unfortunately, effects on gastric emptying were not measured in this study.

\section{Functional dyspepsia}

Functional dyspepsia is characterised by delayed gastric emptying, decreased gastric accommodation and increased visceral
Table 3 Potential GI therapeutic indications for glucagon-like peptide 1 based therapies

\begin{tabular}{|c|c|c|}
\hline Condition & (potential) Mechanisms & Level of evidence \\
\hline $\begin{array}{l}\text { Dumping } \\
\text { syndrome }\end{array}$ & Gastric emptying $\downarrow$ & Case series $^{67}$ \\
\hline $\begin{array}{l}\text { Functional } \\
\text { dyspepsia }\end{array}$ & $\begin{array}{l}\text { Gastric emptying } \downarrow \\
\text { Gastric acid secretion } \downarrow\end{array}$ & Hypothesised \\
\hline Constipated IBS & $\begin{array}{l}\text { Colon circular muscle tone } \downarrow \\
\text { Visceral sensitivity } \downarrow\end{array}$ & $\begin{array}{l}\text { Clinical trials: improved } \\
\text { defaecation pattern, pain } \\
\text { relief }^{8091}\end{array}$ \\
\hline $\begin{array}{l}\text { Short bowel } \\
\text { syndrome }\end{array}$ & Gastric and bowel motility $\downarrow$ & $\begin{array}{l}\text { Clinical trials: reduced } \\
\text { diarrhoea, improved } \\
\text { nutritional status }^{93} 94\end{array}$ \\
\hline $\begin{array}{l}\text { Mucositis and } \\
\text { IBD }\end{array}$ & $\begin{array}{l}\text { Inflammatory parameters } \downarrow \\
\text { Mucosal apoptosis } \downarrow \\
\text { Mucosa proliferation } \uparrow\end{array}$ & $\begin{array}{l}\text { Animal studies: prevention of } \\
\text { loss in mucosal mass in } \\
\text { experimental mucositis } \\
8997\end{array}$ \\
\hline NAFLD & $\begin{array}{l}\text { Weight } \downarrow \\
\text { Hepatic insulin sensitivity } \uparrow \\
\text { Hepatic de novo } \\
\text { lipogenesis } \downarrow \\
\text { Fatty acid oxidation } \uparrow\end{array}$ & $\begin{array}{l}\text { Clinical trials: reduction in } \\
\text { steatosis and } \\
\text { steatohepatitis }^{148155}\end{array}$ \\
\hline Cholangiopathies & $\begin{array}{l}\text { Cholangiocyte proliferation } \uparrow \\
\text { Cholangiocyte apoptosis } \downarrow \\
\text { Bile acid production } \downarrow\end{array}$ & Hypothesised $^{168}$ \\
\hline
\end{tabular}

sensitivity. ${ }^{64}$ In theory, the inhibitory effects of GLP-1RAs on motility could worsen dyspeptic symptoms (tables 3 and 4). On the other hand, their increase in gastric accommodation and decrease in visceral perception may relieve symptoms. ${ }^{36} 65$ Unfortunately, no clinical studies have been performed regarding the effects of GLP-1RAs in this patient group.

\section{Dumping syndrome}

In case of dumping, the gastric inhibitory effects of GLP-1 may slow down transit and thus reduce the hyperosmolar fluid challenge to the proximal intestine, which causes dumping symptoms (nausea, dizziness and fatigue after meals ${ }^{66}$ ). Inhibitory effects on small bowel transit (see below) may contribute, and may additionally reduce abdominal pain and diarrhoea. Recently, a case series demonstrated beneficial effects of liraglutide in seven patients with dumping syndrome after a gastric bypass. $^{67}$ Whether symptoms improved because of reduced gastric emptying or an earlier insulin peak is unclear. Further studies are needed to establish the effects of GLP-1 based therapies in this specific patient population.

\section{Gastroparesis}

The magnitude by which GLP-1RAs decrease gastric emptying depends on baseline gastric motility. ${ }^{68}$ When gastric emptying is already delayed, GLP-1 seems to have little inhibitory effect and the glucose-lowering effect appears reduced. ${ }^{68}$ Thus, in patients with gastroparesis, a common complication of T2DM, ${ }^{69}$ GLP-1RAs may be less effective. Moreover, GLP-1RAs may aggravate symptoms of nausea, vomiting, abdominal pain, early satiety and bloating in patients with (signs of) gastroparesis. Manufacturers currently advise not to use GLP-1RAs in such patients, but evidence is limited and more studies are urgently needed.

\section{Upper GI side effects}

Nausea and vomiting are common side effects of GLP-1RAs, which are minimised by a dose-escalating initiation. ${ }^{70}$ They 
Table 4 Side effects of GLP-1 based therapies

\begin{tabular}{|c|c|c|c|}
\hline \multirow[b]{2}{*}{ Side effect } & \multicolumn{2}{|c|}{ Frequency } & \multirow[b]{2}{*}{ Potential mechanism } \\
\hline & GLP-1RA & DPP-4I & \\
\hline \multicolumn{4}{|l|}{ GI } \\
\hline Nausea & +++ & ++ & $\begin{array}{l}\text { Gastric emptying } \downarrow \text {, activation } \\
\text { nausea centres }\end{array}$ \\
\hline Vomiting & ++ & + & $\begin{array}{l}\text { Gastric emptying } \downarrow \text {, activation } \\
\text { nausea centres }\end{array}$ \\
\hline Diarrhoea & +++ & + & Unknown \\
\hline Constipation & ++ & + & Intestinal motility $\downarrow$ \\
\hline Flatulence & ++ & + & Unknown \\
\hline Gastric reflux & ++ & $+/++$ & Unknown \\
\hline Pancreatitis & $+1-$ & $+1-$ & Unknown \\
\hline Cholelithiasis & $+1-$ & $?$ & $\begin{array}{l}\text { Weight loss, bile acid production } \\
\downarrow \text {, gallbladder motility } \downarrow\end{array}$ \\
\hline \multicolumn{4}{|l|}{ Other } \\
\hline Hypoglycaemia* & +/++ & $+/++$ & $\begin{array}{l}\text { Insulin secretion } \uparrow \text {, intestinal } \\
\text { glucose uptake } \downarrow\end{array}$ \\
\hline Nasopharyngitis & + & + & Unknown \\
\hline Anaphylaxis & $+1-$ & $+1-$ & Immunoreactive \\
\hline Prerenal failure & $+1-$ & $+1-$ & $\begin{array}{l}\text { Dehydration by vomiting, diuresis } \\
\uparrow\end{array}$ \\
\hline \multicolumn{4}{|c|}{$\begin{array}{l}\text { Based on the summary product characteristics of all registered GLP-1RA and DPP-4I. } \\
\text { "Predominantly observed in combination with sulfonylurea agents, not with } \\
\text { metformin. } \\
+++ \text {, very common }(>1 / 10) ;++ \text {, common }(>1 / 100) ;+ \text {, uncommon }(>1 / 1000) ;++- \text {, } \\
\text { rare to very rare }(>1 / 10000) ;- \text {, not present; ?, unknown. } \\
\text { DPP-4l, dipeptidyl peptidase } 4 \text { inhibitor; GLP-1RA, glucagon-like peptide-1 receptor } \\
\text { agonist. }\end{array}$} \\
\hline
\end{tabular}

occur in at least $25 \%$ of patients and, although often shortlasting, are a major cause for drug discontinuation. ${ }^{71}$ After 6 months of treatment, nausea remains present in 3\% with longacting and $9 \%$ with short-acting GLP-1RAs. ${ }^{42} 71$ These numbers were mostly acquired by self-reporting, but even when a validated questionnaire was used, liraglutide significantly increased 'indigestion' scores, compared with placebo. ${ }^{72}$ It has long been suggested that these effects are caused by inhibition of gastric emptying. This would explain the absence of nausea with DPP-4Is, and the abating effect with long-acting GLP-1RAs, because of tachyphylaxis. However, nausea also occurs in fasting patients ${ }^{73}$ and its presence is not closely correlated to gastric emptying inhibition. ${ }^{34}$ Recent animal studies suggest that central neurological nausea circuits are involved, but human evidence is still lacking. ${ }^{74}$ Also, why these side effects are common after subcutaneous injection and rare after intravenous administration is still unresolved. ${ }^{75}$

Another frequent complaint with GLP-1RAs is (nocturnal) gastro-oesophageal reflux. ${ }^{72}$ This seems surprising, since GLP-1 reduces gastric pressure and acid secretion. ${ }^{36} 76$ Perhaps, GLP-1 (RA)s also reduce gastro-oesophageal sphincter pressure, but this has not been investigated yet.

\section{Small and large intestines}

GLP-1(RA) infusion evidently decreases small bowel activity, as observed by a reduction in migratory motor complexes in the fasting state and a reduction in postprandial spiking activity. ${ }^{32} 7778$ The colonic effects of GLP-1 are less clear. ${ }^{32}$ GLP-1 seems to inhibit colonic motility, as was shown by reduced circular contractions in full thickness muscular colon strips. ${ }^{79} 80$ Notably, a reduction in glycaemia tends to increase intestinal motility, thus the direct inhibitory effect of GLP-1 and GLP-1RAs are likely to be underestimated in these studies. ${ }^{81}$
Similar to the gastric responses, the intestinal effects appear to be indirect and are probably mediated through neuronal involvement. ${ }^{40798283}$

Exogenous GLP-1 affects intestinal motility, and morphology and absorption. GLP-1RAs and DPP-4Is decrease intestinal absorption of triglycerides and lower plasma levels of apolipoprotein B48 and triglycerides. ${ }^{68}$ 84-87 In healthy rodents, mucosal mass and intestinal length increased after 12 weeks of treatment with a GLP-1RA, but not with a DPP-4I. ${ }^{88}$ However, in an animal model of experimental colitis, DPP-4I did restore mucosal damage. ${ }^{89}$ Thus, GLP-1RAs and DPP-4Is seem to have proliferative effects on intestinal epithelial cells. This combination of decreased motility and absorption further inhibits glucose absorption. ${ }^{68} 78$

\section{Clinical implications \\ Irritable bowel syndrome}

Though contraintuitive, patients with constipation-predominant IBS (c-IBS) may benefit from GLP-1 effects (tables 3 and 4). In these patients, symptoms seem to be caused by abnormal contractions of the circular colonic muscles, which are reduced by GLP-1 ${ }^{79}$ Indeed, a placebo-controlled trial showed that the GLP-1RA ROSE-010 improved scintigraphically measured colonic transit time in patients with c-IBS. ${ }^{80}$ Furthermore, highdose GLP-1 infusion reduced migratory motor complexes and intestinal motility in patients with IBS. ${ }^{77}$ Data from animal studies suggests that GLP-1RAs also decreases visceral sensitivity. ${ }^{90}$ In a double-blind randomised prospective trial in humans, pain relief, assessed with a visual analogue score, was higher with ROSE-010, as compared with placebo. ${ }^{91}$ Since T2DM and IBS frequently coincide, GLP-1RAs might be of double benefit to these patients. ${ }^{92}$

\section{Short bowel syndrome}

Malabsorption is a frequent problem in short bowel syndrome, obviously caused by the reduced intestinal absorbent surface. Loss of the terminal ileum also eradicates the ileal brake mechanism, further compromising digestion. Infusion of GLP-1 peptide significantly reduced diarrhoea and faecal excretions in patients with short bowel, as compared with placebo. ${ }^{93}$ Similar findings were observed in five cases for the short-acting GLP-1RA exenatide twice daily. ${ }^{94}$ Although not studied, longacting GLP-1RAs are probably not as effective, since they have little effect on gastric emptying. A cause of potential concern is the inhibiting effect of GLP-1RAs on appetite, since patients with short bowel syndrome need adequate energy and electrolyte intake. ${ }^{93}$

Effects of DPP-4Is have not been studied in this population, yet other non-GLP-1-substrates of DPP-4 seem to benefit the clinical condition and quality of life of this patient group. For example, GLP-2 improves intestinal absorption and the nutritional status in patients with short bowel syndrome. ${ }^{95}$ Recently, the GLP-2RA teduglutide was approved for the treatment of short bowel syndrome. ${ }^{96}$ Combined infusion of GLP-1 and GLP-2 led to greater effects on intestinal absorption, compared with infusion of either peptide alone, suggesting that DPP-4 inhibition may be highly effective in these patients. ${ }^{93}$

\section{Mucosal healing in mucositis and IBD}

The proliferative effect of GLP-1RAs and DPP-4Is on intestinal mucosa provides possibilities for treatment of chemotherapyinduced mucositis. In animal studies, pharmacological levels of exogenous GLP-1 ameliorated 5-fluorouracil-induced mucositis. ${ }^{97}$ Although DPP-4Is have no effect on healthy mucosa, the DPP-4I 
anagliptin restored mucosal damage in an animal model of experimental colitis. ${ }^{89}$ Also, DPP-4 inhibition increases levels of active GLP-2 and stromal-derived factor- $1 \alpha$, both of which are involved in mucosal healing. ${ }^{88} 97$ These animal studies evidently call for further investigation.

Currently, there are no data confirming that GLP-1 based therapies ameliorate IBD. However, administration of GLP-1RAs or DPP-4Is reduced systemic inflammatory parameters. ${ }^{98} 99$ In addition, GLP-1RAs lower inflammatory activity in psoriasis. ${ }^{100}$ This combination of mucosal healing and alleviation of systemic inflammation may bare new possibilities for treatment of IBD.

\section{Intestinal side effects: constipation and diarrhoea}

Many patients experience constipation or, in contrast, diarrhoea, while using GLP-1 based drugs. ${ }^{72} 101$ Constipation may be caused by a decrease in colonic muscle contractions. ${ }^{79}$ An explanation for diarrhoea is lacking. In one study, patients experienced osmotic diarrhoea, $8 \mathrm{~h}$ after administration of GLP-1. ${ }^{102}$ Potentially, the intestinal effects of GLP-1 reduce absorption, thereby leading to increased osmosis. Reduced pancreatic exocrine excretion may also play a role, causing malabsorption (see below). ${ }^{103} 104$

\section{Colon carcinoma}

Although cell proliferation is beneficial for mucosal healing, it may also induce dysplasia. In mice with familial adenomatous polyposis, GLP-1 and GLP-1RAs increased polyp numbers and size. ${ }^{105}$ After bariatric surgery, which increases GLP-1 levels, the incidence of colorectal cancer is elevated. ${ }^{106}$ Consequently, GLP-1 based therapies should be used with caution in subjects at risk for colorectal cancer, until further studies become available.

\section{Exocrine pancreas}

Intravenous infusion of GLP-1 reduces pancreatic exocrine function in preclinical and human studies. ${ }^{103} 104107$ In pigs, GLP-1 reduced bicarbonate secretion. ${ }^{107}$ Administration to healthy volunteers led to an immediate decrease in pancreatic trypsin and lipase secretion of over 40\%. ${ }^{103} 104$ Underlying mechanisms are incompletely understood. Direct stimulation of acinar cells by GLP-1 did not affect pancreatic amylase secretion in vitro. ${ }^{108}$ Again, indirect mediators are likely, possibly through vagal nerve activation or through the pancreas-stimulating hormones secretin and cholecystokinin (CCK). ${ }^{39} 107$ Also, the (GLP-1 induced) gastric effects decrease duodenal acidity, which is a major stimulus for secretin/CCK secretion. Thus, inhibition of exocrine secretion may be partly mediated by gastric responses. ${ }^{103}$ To date, the influence of GLP-1 based drugs on exocrine pancreatic function remains unstudied.

\section{Clinical implications \\ Pancreatitis and pancreatic carcinoma}

Soon after their introduction, GLP-1 based drugs were linked to development of pancreatitis and pancreatic cancer ${ }^{109}$ (tables 3 and 4). In patients with T2DM using GLP-1 based drugs, a subtle and asymptomatic increase in plasma lipase and amylase levels was observed, ${ }^{110} 111$ suggesting subclinical inflammation or pancreatic duct obstruction. Findings from animal studies are conflicting. A handful of studies showed that GLP-1RAs induce pancreatic inflammation, cellular proliferation and intraepithelial neoplasia (PanIN). ${ }^{112-114}$ One study found an association between the DPP-4I sitagliptin and pancreatitis, ductal cell replication and metaplasia in a rat model of diabetes. ${ }^{115}$ However, the majority of animal studies did not find any effect of GLP-1RAs or DPP-4Is on pancreatic physiology, even with a 240 times increased dose. ${ }^{116-122}$ Notably, some studies even suggested that GLP-1RAs decreases inflammation and malignant degeneration. $^{114} 123-125$

Few human histological studies are available. In a study in pancreatic donors, including 12 patients with diabetes without GLP-1 based therapy, 7 using sitagliptin and 1 exenatide, GLP-1 based therapy was associated with $\alpha$-cell hyperplasia and PanIN lesions. ${ }^{126}$ However, re-analyses showed that the treatment and control groups in this study were severely mismatched, which probably induced confounding. ${ }^{127} 128$ A recent study has demonstrated the absence of the GLP-1R on human pancreatic ductal cells, ${ }^{10}$ which contradicts the hypothesis that GLP-1R activation leads to ductal cell proliferation. ${ }^{113}$

Clinical data are available from pharmacovigilance studies, database studies and randomised clinical trials (RCTs). Pharmacovigilance studies have shown associations between GLP-1RAs and DPP-4Is and acute pancreatitis and pancreatic carcinoma. ${ }^{109}$ However, since these studies depend on spontaneous reporting by clinicians, they become notably unreliable when a certain side effect receives media attention, as happened in this case. Additionally, they lack information on confounders. Indeed, patients with T2DM often have concomitant risk factors for pancreatitis, including obesity, long-standing disease and use of comedication. Importantly, these factors are likely to be more present in patients with an indication for GLP-1 based therapy.

In contrast, healthcare databases are able to correct for potential confounding. These did not show a relation between GLP-1 based therapies and pancreatic adverse events, ${ }^{129-134}$ except for a single study. In this case, a combined analysis of exenatide and sitagliptin was performed. ${ }^{135}$ When each drug was analysed separately, however, no association with pancreatitis was found. Four recent large-scale RCTs, axagliptin Assessment of Vascular Outcomes Recorded in Patients with Diabetes Mellitus Thrombolysis in Myocardial Infarction (SAVOR-TIMI 53) (saxagliptin), Examination of Cardiovascular Outcomes with Alogliptin versus Standard of Care in PAtients with Type 2 Diabetes Mellitus and Acute Coronary Syndrome (EXAMINE) (alogliptin), Trial to Evaluate Cardiovascular Outcomes After Treatment with Sitagliptin (TECOS) (sitagliptin) and Evaluation of Lixisenatide in Acute Coronary Syndrome (ELIXA) (lixisenatide), which investigated the cardiovascular safety of DPP-4Is and GLP-1RAs, did not identify an increased risk of pancreatitis or pancreatic cancer. ${ }^{136-139}$ Notably, a trend towards an increased incidence of acute pancreatitis with sitagliptin was seen $(0.3 \%$ vs $0.2 \%$ with placebo, $\mathrm{p}$ value 0.066$) .{ }^{138}$ However, these trials did not have sufficient power and follow-up to investigate rare side effects. A meta-analysis did not find any association with acute pancreatitis, although the most recent studies were not included and an update is needed. ${ }^{140}$

Recently, the regulatory authorities have reviewed all available preclinical and clinical evidence, and found no causal association between GLP-1 based therapies and pancreatic adverse events. ${ }^{141}$ Yet, all studies combined, evidence is still scarce and the follow-up time of current studies may be too short for the development of pancreatic cancer. Thus final conclusions cannot be made. Until further data become available, it is highly recommended not to use these agents in patients with a (family) history of pancreatic disease.

\section{Liver and biliary system}

GLP-1 induces several metabolic changes in the liver, adding to lower glucose and lipid levels. Independent from insulin and 
glucagon, GLP-1 stimulates hepatic glycogen storage, while suppressing gluconeogenesis. ${ }^{142}{ }^{143}$ It increases mitochondrial degradation of fatty acids and inhibits triglyceride production. ${ }^{144} 145$ In addition, GLP-1 influences bile metabolism. ${ }^{87}$ It lowers bile acid production and increases excretion, thereby lowering the bile acid exposure of hepatocytes. ${ }^{146}$ In vitro, GLP-1 and the GLP-1RA exendin-4 increase cholangiocyte proliferation and reduce apoptosis. ${ }^{147}$ Moreover, a single dose of exenatide decreased CCK-induced gallbladder contractions in healthy humans. ${ }^{28}$ Combined, these biliary effects may potentially prevent secondary biliary cirrhosis in patients with cholangiopathies.

\section{Clinical implications}

\section{Non-alcoholic fatty liver disease}

GLP-1 based therapies seem to be beneficial in NAFLD and non-alcoholic steatohepatitis (NASH) (tables 3 and 4). In several animal models, GLP-1 based therapies decreased steatosis and hepatic damage. ${ }^{148}$ Evidence in humans is less conclusive. Studies showed a reduction in transaminase levels and spectroscopy-measured steatosis, after treatment with GLP-1RAs or DPP-4Is in patients with T2DM and ultrasonography-proven or biopsy-proven NAFLD. ${ }^{149-152}$ Likewise, on histology, 1 year of treatment with sitagliptin improved NASH severity. ${ }^{153}$ However, none of these trials had an adequate control group, precluding definite conclusions. Three recent RCTs are of interest. In patients with T2DM, insulin glargine reduced MRI-measured hepatic fat, while liraglutide had no effect. ${ }^{154}$ Sitagliptin reduced steatosis significantly more than sulfonylurea derivates. ${ }^{155}$ In patients with biopsy-confirmed NASH (with or without diabetes), 48 weeks of liraglutide treatment was associated with histological resolution of steatohepatitis. ${ }^{156}$

The mechanisms underlying the effects of GLP-1 based therapies on NAFLD remain speculative. Steatosis is induced by obesity and insulin resistance, while inflammatory cytokines, bacterial endotoxins, mitochondrial dysfunction and/or endoplasmic reticulum stress further lead towards steatohepatitis. ${ }^{157} 158$ As GLP-1RAs and DPP-4Is increase hepatic insulin sensitivity, this may explain the beneficial effect on NAFLD. ${ }^{159-162}$ GLP-1-induced improvement of hepatic triglyceride handling probably also plays a role. Furthermore, GLP-1RAs and DPP-4Is reduce hepatocyte endoplasmic reticulum stress ${ }^{163} 164$ and inflammatory cytokines, ${ }^{164}{ }^{165}$ both involved in NASH development.

\section{Cholelithiasis}

High-dose liraglutide treatment has been related to increased occurrence of cholelithiasis and cholecystitis in studies, investigating this drug as weight-reducing agent. ${ }^{166}$ The underlying mechanism remains unclear, but may involve altered bile acid production and excretion, decreased gallbladder emptying or liraglutide-induced weight loss.

\section{CONCLUSIONS AND FUTURE PERSPECTIVES}

The GLP-1 based drugs, GLP-1RAs and DPP-4Is, are increasingly used to treat T2DM. Apart from their insulinotropic effects, their GI effects provide therapeutic possibilities for a wide scale of GI diseases, including functional dyspepsia, dumping syndrome, IBS, IBD, short bowel syndrome, NAFLD/ NASH and cholestatic disorders. Since digestive disorders frequently coincide with T2DM, GLP-1 based drugs may have added benefits in these patient groups.

The recent registration of liraglutide for weight loss confirms the safety of these agents in normoglycaemic subjects, and creates possibilities for a more general application in GI disease. However, evidence is still mechanistic in nature, and not solid enough to direct clinical care. To gain approval for such indications, more studies are needed, which will take time. While results from ongoing studies on NAFLD are eagerly awaited (clinicaltrials.gov: NCT01237119, NCT02147925 and NCT01744236), large-scale RCTs with adequate control groups are needed to establish safety and efficacy for other applications.

On the other hand, GLP-1 based therapies frequently cause GI side effects, such as nausea, constipation and diarrhoea, which need to be recognised. Such side effects may limit the use of these drugs in patients with pre-existing GI symptoms, which are common; in a self-reported study, nausea, heartburn, early satiety, diarrhoea and constipation were all more prevalent in patients with diabetes than in controls. ${ }^{167}$ Also, reports of serious adverse events (ie, acute pancreatitis, pancreatic cancer) need to be acknowledged. Although an increased risk was never proven, these issues need to be clarified, before GLP-1 based therapies can be advocated for treatment of GI disorders.

Finally, to enhance patient comfort, respiratory and oral administration routes of GLP-1RAs are currently being developed. Whether these agents will exert similar metabolic and GI effects needs to be investigated. Hypothetically, oral GLP-1RA could reach high portal levels, and thus be extra beneficial for NAFLD. Inhalation of (very) short-acting GLP-1RA could strongly and briefly reduce gastric emptying, and thus be beneficial for dumping syndrome.

In conclusion, understanding the GI actions of GLP-1 based therapies is clinically relevant for diabetologists and gastroenterologists, because GI side effects are common and need to be recognised, and because these drugs may potentially be applied to treat GI disease.

Contributors MMS, LT, MHAM and DHvR researched the literature and (re)wrote the article. All authors (MMS, LT, MHAM, MHHK, DLC and DHvR) made a substantial contribution to the discussion of the content, and reviewed and edited the manuscript before submission.

Competing interests Through MHHK, the VU University Medical Center received research grants from Boehringer-Ingelheim, Novo Nordisk and Sanofi. The other authors declared no competing interests.

Provenance and peer review Not commissioned; externally peer reviewed.

\section{REFERENCES}

1 Holst JJ. The physiology of glucagon-like peptide 1. Physiol Rev 2007:87:1409-39.

2 Inzucchi SE, Bergenstal RM, Buse JB, et al. Management of hyperglycaemia in type 2 diabetes, 2015: a patient-centred approach. Update to a position statement of the American Diabetes Association and the European Association for the Study of Diabetes. Diabetologia 2015;58:429-42.

3 Abu-Hamdah R, Rabiee A, Meneilly GS, et al. Clinical review: the extrapancreatic effects of glucagon-like peptide-1 and related peptides. J Clin Endocrinol Metab 2009;94:1843-52

4 Smits MM, Tonneijck L, Muskiet MHA, et al. Gastrointestinal actions of GLP-1 based therapies: glycaemic control beyond the pancreas. Diabetes Obes Metab Published Online First: 24 Oct 2015. doi: 10.1111/dom.12593

5 Eissele R, Göke R, Willemer S, et al. Glucagon-like peptide-1 cells in the gastrointestinal tract and pancreas of rat, pig and man. Eur J Clin Invest 1992;22:283-91.

6 Ezcurra M, Reimann F, Gribble FM, et al. Molecular mechanisms of incretin hormone secretion. Curr Opin Pharmacol 2013;13:922-7.

$7 \mathrm{Ma}$ J, Bellon M, Wishart JM, et al. Effect of the artificial sweetener, sucralose, on gastric emptying and incretin hormone release in healthy subjects. Am J Physiol Gastrointest Liver Physiol 2009;296:G735-9.

8 Temizkan S, Deyneli O, Yasar M, et al. Sucralose enhances GLP-1 release and lowers blood glucose in the presence of carbohydrate in healthy subjects but not in patients with type 2 diabetes. Eur J Clin Nutr 2015;69:162-6.

9 Balks HJ, Holst JJ, von zur Mühlen A, et al. Rapid oscillations in plasma glucagon-like peptide-1 (GLP-1) in humans: cholinergic control of GLP-1 secretion via muscarinic receptors. J Clin Endocrinol Metab 1997;82:786-90. 
10 Pyke C, Heller RS, Kirk RK, et al. GLP-1 Receptor Localization in Monkey and Human Tissue: Novel Distribution Revealed With Extensively Validated Monoclonal Antibody. Endocrinology 2014;155:1280-90.

11 Körner M, Stöckli M, Waser B, et al. GLP-1 receptor expression in human tumors and human normal tissues: potential for in vivo targeting. J Nucl Med 2007; 48:736-43.

12 Tomas E, Habener JF. Insulin-like actions of glucagon-like peptide-1: a dual receptor hypothesis. Trends Endocrinol Metab 2010;21:59-67.

13 Mentlein R, Gallwitz B, Schmidt WE. Dipeptidyl-peptidase IV hydrolyses gastric inhibitory polypeptide, glucagon-like peptide-1(7-36)amide, peptide histidine methionine and is responsible for their degradation in human serum. Eur J Biochem 1993:214:829-35.

14 Meier JJ, Nauck MA, Kranz D, et al. Secretion, degradation, and elimination of glucagon-like peptide 1 and gastric inhibitory polypeptide in patients with chronic renal insufficiency and healthy control subjects. Diabetes 2004;53:654-62.

15 Deacon CF, Pridal L, Klarskov L, et al. Glucagon-like peptide 1 undergoes differential tissue-specific metabolism in the anesthetized pig. Am J Physiol 1996;271:E458-64

16 Imeryüz N, Yeğen BC, Bozkurt A, et al. Glucagon-like peptide-1 inhibits gastric emptying via vagal afferent-mediated central mechanisms. Am J Physiol 1997;273: G920-7.

17 Plamboeck A, Veedfald S, Deacon CF, et al. The effect of exogenous GLP-1 on food intake is lost in male truncally vagotomized subjects with pyloroplasty. Am J Physiol Gastrointest Liver Physiol 2013;304:G1117-27.

18 Kolligs F, Fehmann H-C, Goke R, et al. Reduction of the incretin effect in rats by the glucagon-like peptide 1 receptor antagonist exendin (9-39) amide. Diabetes 1995:44:16-19.

19 Schirra J, Sturm K, Leicht $P$, et al. Exendin(9-39)amide is an antagonist of glucagon-like peptide-1(7-36)amide in humans. I Clin Invest 1998;101: 1421-30.

20 Schirra J, Nicolaus M, Roggel R, et al. Endogenous glucagon-like peptide 1 controls endocrine pancreatic secretion and antro-pyloro-duodenal motility in humans. Gut 2006:55:243-51.

21 Van Citters GW, Lin HC. Ileal brake: neuropeptidergic control of intestinal transit. Curr Gastroenterol Rep 2006;8:367-73.

22 Maljaars PWJ, Peters HPF, Mela DJ, et al. lleal brake: a sensible food target for appetite control. A review. Physiol Behav 2008;95:271-81.

23 Deane AM, Nguyen NQ, Stevens JE, et al. Endogenous glucagon-like peptide-1 slows gastric emptying in healthy subjects, attenuating postprandial glycemia. J Clin Endocrinol Metab 2010;95:215-21.

24 Aulinger BA, Bedorf A, Kutscherauer G, et al. Defining the role of GLP-1 in the enteroinsulinar axis in type 2 diabetes using DPP-4 inhibition and GLP-1 receptor blockade. Diabetes 2014;63:1079-92.

25 Schirra J, Nicolaus M, Woerle HJ, et al. GLP-1 regulates gastroduodenal motility involving cholinergic pathways. Neurogastroenterol Motil 2009:21:609-18, e21-2.

26 Witte A-B, Grybäck P, Jacobsson $H$, et al. Involvement of endogenous glucagon-like peptide-1 in regulation of gastric motility and pancreatic endocrine secretion. Scand I Gastroenterol 2011;46:428-35.

27 Horowitz M, Nauck MA. To be or not to be-an incretin or enterogastrone? Gut 2006;55:148-50.

28 Keller J, Trautmann ME, Haber $\mathrm{H}$, et al. Effect of exenatide on cholecystokinin-induced gallbladder emptying in fasting healthy subjects. Regul Pept 2012;179:77-83.

29 DeFronzo RA, Okerson T, Viswanathan P, et al. Effects of exenatide versus sitagliptin on postprandial glucose, insulin and glucagon secretion, gastric emptying, and caloric intake: a randomized, cross-over study. Curr Med Res Opin 2008:24:2943-52

30 Meier JJ, Nauck MA. Incretin-based therapies: where will we be 50 years from now?. Diabetologia 2015;58:1745-50.

31 Scheen AJ. Once-weekly DPP-4 inhibitors: do they meet an unmet need? Lancet Diabetes Endocrinol 2015;3:162-4.

32 Marathe CS, Rayner CK, Jones KL, et al. Effects of GLP-1 and incretin-based therapies on gastrointestinal motor function. Exp Diabetes Res 2011;2011:279530

33 Trahair LG, Horowitz M, Hausken T, et al. Effects of exogenous glucagon-like peptide-1 on the blood pressure, heart rate, mesenteric blood flow, and glycemic responses to intraduodenal glucose in healthy older subjects. J Clin Endocrinol Metab 2014;99:E2628-34.

34 Linnebjerg $\mathrm{H}$, Park $\mathrm{S}$, Kothare PA, et al. Effect of exenatide on gastric emptying and relationship to postprandial glycemia in type 2 diabetes. Regul Pept 2008:151:123-9.

35 Schirra J, Kuwert P, Wank U, et al. Differential effects of subcutaneous GLP-1 on gastric emptying, antroduodenal motility, and pancreatic function in men. Proc Assoc Am Phys 1997;109:84-97.

36 Schirra J, Wank U, Arnold R, et al. Effects of glucagon-like peptide-1(7-36)amide on motility and sensation of the proximal stomach in humans. Gut 2002;50:341-8
37 Little TJ, Pilichiewicz AN, Russo A, et al. Effects of intravenous glucagon-like peptide-1 on gastric emptying and intragastric distribution in healthy subjects: relationships with postprandial glycemic and insulinemic responses. J Clin Endocrinol Metab 2006:91:1916-23.

38 Wettergren A, Wøjdemann $M$, Meisner $S$, et al. The inhibitory effect of glucagon-like peptide-1 (GLP-1) 7-36 amide on gastric acid secretion in humans depends on an intact vagal innervation. Gut 1997;40:597-601.

39 Wøjdemann M, Wettergren A, Sternby B, et al. Inhibition of human gastric lipase secretion by glucagon-like peptide-1. Dig Dis Sci 1998;43:799-805.

40 Tolessa T, Gutniak M, Holst JJ, et al. Glucagon-like peptide-1 retards gastric emptying and small bowel transit in the rat: effect mediated through central or enteric nervous mechanisms. Dig Dis Sci 1998;43:2284-90.

41 Jelsing J, Vrang N, Hansen G, et al. Liraglutide: short-lived effect on gastric emptying - long lasting effects on body weight. Diabetes Obes Metab 2012;14:531-8

42 Drucker DJ, Buse JB, Taylor K, et al. Exenatide once weekly versus twice daily for the treatment of type 2 diabetes: a randomised, open-label, non-inferiority study. Lancet 2008;372:1240-50.

43 Dejgaard TF, Frandsen CS, Hansen TS, et al. Efficacy and safety of liraglutide for overweight adult patients with type 1 diabetes and insufficient glycaemic contro (Lira-1): a randomised, double-blind, placebo-controlled trial. Lancet Diabetes Endocrinol 2015. Published Online First: 2 December 2015. doi: 10.1016/S22138587(15)00436-2

44 Nauck MA, Kemmeries G, Holst JJ, et al. Rapid tachyphylaxis of the glucagon-like peptide 1 -induced deceleration of gastric emptying in humans. Diabetes 2011:60:1561-5.

45 Umapathysivam MM, Lee MY, Jones KL, et al. Comparative effects of prolonged and intermittent stimulation of the glucagon-like peptide 1 receptor on gastric emptying and glycemia. Diabetes 2014;63:785-90.

46 Vella A, Bock G, Giesler PD, et al. Effects of dipeptidyl peptidase-4 inhibition on gastrointestinal function, meal appearance, and glucose metabolism in type 2 diabetes. Diabetes 2007;56:1475-80.

47 Stevens JE, Horowitz M, Deacon CF, et al. The effects of sitagliptin on gastric emptying in healthy humans - a randomised, controlled study. Aliment Pharmacol Ther 2012;36:379-90.

48 Mari A, Sallas WM, He YL, et al. Vildagliptin, a dipeptidyl peptidase-IV inhibitor, improves model-assessed beta-cell function in patients with type 2 diabetes. J Clin Endocrinol Metab 2005;90:4888-94.

49 Näslund E, Bogefors J, Skogar S, et al. GLP-1 slows solid gastric emptying and inhibits insulin, glucagon, and PYY release in humans. Am J Physiol 1999;277: R910-16.

50 Witte A-B, Grybäck P, Holst JJ, et al. Differential effect of PYY1-36 and PYY3-36 on gastric emptying in man. Regul Pept 2009;158:57-62.

51 Marathe CS, Rayner CK, Jones KL, et al. Relationships between gastric emptying, postprandial glycemia, and incretin hormones. Diabetes Care 2013;36:1396-405.

52 Plummer MP, Jones KL, Cousins $C E$, et al. Hyperglycemia potentiates the slowing of gastric emptying induced by exogenous GLP-1. Diabetes Care 2015;38:1123-9.

53 Plummer MP, Jones KL, Annink CE, et al. Glucagon-like peptide 1 attenuates the acceleration of gastric emptying induced by hypoglycemia in healthy subjects. Diabetes Care 2014;37:1509-15.

54 Schvarcz E, Palmér M, Aman J, et al. Physiological hyperglycemia slows gastric emptying in normal subjects and patients with insulin-dependent diabetes mellitus. Gastroenterology 1997;113:60-6.

55 O'Donovan DG, Doran S, Feinle-Bisset C, et al. Effect of variations in small intestinal glucose delivery on plasma glucose, insulin, and incretin hormones in healthy subjects and type 2 diabetes. J Clin Endocrinol Metab 2004;89:3431-5.

56 Marathe CS, Horowitz M, Trahair LG, et al. Relationships of early and late glycemic responses with gastric emptying during an oral glucose tolerance test. $J$ Clin Endocrinol Metab 2015;100:3565-71.

57 Lorenz M, Pfeiffer C, Steinsträsser A, et al. Effects of lixisenatide once daily on gastric emptying in type 2 diabetes-relationship to postprandial glycemia. Regul Pept 2013;185:1-8.

58 Meier JJ, Kemmeries G, Holst JJ, et al. Erythromycin antagonizes the deceleration of gastric emptying by glucagon-like peptide 1 and unmasks its insulinotropic effect in healthy subjects. Diabetes 2005;54:2212-18.

59 Sun F, Chai S, Li L, et al. Effects of glucagon-like peptide-1 receptor agonists on weight loss in patients with type 2 diabetes: a systematic review and network meta-analysis. J Diabetes Res 2015;2015:1-9.

60 Pi-Sunyer X, Astrup A, Fujioka K, et al. A randomized, controlled trial of $3.0 \mathrm{mg}$ of liraglutide in weight management. $N$ Engl I Med 2015;373:11-22.

61 Rotondo A, Janssen P, Mulè F, et al. Effect of the GLP-1 analog liraglutide on satiation and gastric sensorimotor function during nutrient-drink ingestion. Int J Obes 2013;37:693-8.

62 van Bloemendaal L, Ten Kulve JS, la Fleur SE, et al. Effects of glucagon-like peptide 1 on appetite and body weight: focus on the CNS. J Endocrinol 2014;221:T1-16.

63 Ten Kulve JS, Veltman DJ, van Bloemendaal L, et al. Liraglutide reduces CNS activation in response to visual food cues only after short-term treatment in 
patients with type 2 diabetes. Diabetes Care 2015. Published Online First: 17 August 2015

64 Tack J, Bisschops R, Sarnelli G. Pathophysiology and treatment of functional dyspepsia. Gastroenterology 2004;127:1239-55.

65 Tack J, Janssen P, Masaoka T, et al. Efficacy of buspirone, a fundus-relaxing drug, in patients with functional dyspepsia. Clin Gastroenterol Hepatol 2012;10:1239-45.

66 Berg P, McCallum R. Dumping syndrome: a review of the current concepts of pathophysiology, diagnosis, and treatment. Dig Dis Sci 2016;61:11-8.

67 Stier CK. Unreported therapeutic effect of liraglutide in dumping syndrome. Diabetes 2015;64 (Suppl).

68 Deane AM, Chapman MJ, Fraser RJL, et al. Effects of exogenous glucagon-like peptide-1 on gastric emptying and glucose absorption in the critically ill: relationship to glycemia. Crit Care Med 2010;38:1261-9.

69 Kashyap P, Farrugia G. Diabetic gastroparesis: what we have learned and had to unlearn in the past 5 years. Gut 2010;59:1716-26.

70 Fineman MS, Shen LZ, Taylor K, et al. Effectiveness of progressive dose-escalation of exenatide (exendin-4) in reducing dose-limiting side effects in subjects with type 2 diabetes. Diabetes Metab Res Rev 2004;20:411-17.

71 Buse JB, Rosenstock J, Sesti G, et al. Liraglutide once a day versus exenatide twice a day for type 2 diabetes: a 26-week randomised, parallel-group, multinational, open-label trial (LEAD-6). Lancet 2009;374:39-47.

72 Horowitz M, Vilsbøll T, Zdravkovic M, et al. Patient-reported rating of gastrointestinal adverse effects during treatment of type 2 diabetes with the once-daily human GLP-1 analogue, liraglutide. Diabetes Obes Metab 2008;10:593-6.

73 Willms B, Werner J, Holst JJ, et al. Gastric emptying, glucose responses, and insulin secretion after a liquid test meal: effects of exogenous glucagon-like peptide-1 (GLP-1)-(7-36) amide in type 2 (noninsulin-dependent) diabetic patients. J Clin Endocrinol Metab 1996;81:327-32.

74 Kanoski SE, Rupprecht LE, Fortin SM, et al. The role of nausea in food intake and body weight suppression by peripheral GLP-1 receptor agonists, exendin-4 and liraglutide. Neuropharmacology 2012;62:1916-27.

75 Nauck MA, Baranov 0, Ritzel RA, et al. Do current incretin mimetics exploit the full therapeutic potential inherent in GLP-1 receptor stimulation? Diabetologia 2013;56:1878-83.

76 Schjoldager BT, Mortensen PE, Christiansen J, et al. GLP-1 (glucagon-like peptide 1) and truncated GLP-1, fragments of human proglucagon, inhibit gastric acid secretion in humans. Dig Dis Sci 1989;34:703-8.

77 Hellström PM, Näslund E, Edholm T, et al. GLP-1 suppresses gastrointestinal motility and inhibits the migrating motor complex in healthy subjects and patients with irritable bowel syndrome. Neurogastroenterol Motil 2008;20:649-59.

78 Thazhath SS, Marathe CS, Wu T, et al. The glucagon-like peptide 1 (GLP-1) receptor agonist exenatide inhibits small intestinal motility, flow, transit, and absorption of glucose in healthy subjects and patients with type 2 diabetes: a randomized controlled trial. Diabetes 2016;65:269-75.

79 Amato A, Baldassano S, Liotta R, et al. Exogenous glucagon-like peptide 1 reduces contractions in human colon circular muscle. J Endocrinol 2014;221:29-37.

80 Camilleri $\mathrm{M}$, Vazquez-Roque $\mathrm{M}$, Iturrino J, et al. Effect of a glucagon-like peptide 1 analog, ROSE-010, on GI motor functions in female patients with constipation-predominant irritable bowel syndrome. Am J Physiol Gastrointest Liver Physiol 2012;303:G120-8.

81 Rayner CK, Samsom M, Jones KL, et al. Relationships of upper gastrointestinal motor and sensory function with glycemic control. Diabetes Care 2001;24:371-81.

82 Amato A, Cinci L, Rotondo A, et al. Peripheral motor action of glucagon-like peptide-1 through enteric neuronal receptors. Neurogastroenterol Motil 2010;22:664-e203.

83 Tolessa T, Gutniak M, Holst JJ, et al. Inhibitory effect of glucagon-like peptide-1 on small bowel motility. Fasting but not fed motility inhibited via nitric oxide independently of insulin and somatostatin. J Clin Invest 1998;102:764-74.

84 Hsieh J, Longuet C, Baker CL, et al. The glucagon-like peptide 1 receptor is essential for postprandial lipoprotein synthesis and secretion in hamsters and mice. Diabetologia 2010;53:552-61.

85 Xiao C, Bandsma RHJ, Dash S, et al. Exenatide, a glucagon-like peptide-1 receptor agonist, acutely inhibits intestinal lipoprotein production in healthy humans. Arterioscler Thromb Vasc Biol 2012;32:1513-19.

86 Xiao C, Dash S, Morgantini C, et al. Sitagliptin, a DPP-4 inhibitor, acutely inhibits intestinal lipoprotein particle secretion in healthy humans. Diabetes 2014;63:2394-401.

87 Hermansen $K$, Bækdal TA, Düring $M$, et al. Liraglutide suppresses postprandial triglyceride and apolipoprotein B48 elevations after a fat-rich meal in patients with type 2 diabetes: a randomized, double-blind, placebo-controlled, cross-over trial. Diabetes Obes Metab 2013;15:1040-8.

88 Simonsen L, Pilgaard S, Orskov C, et al. Exendin-4, but not dipeptidyl peptidase IV inhibition, increases small intestinal mass in GK rats. Am J Physiol Gastrointest Liver Physiol 2007;293:G288-95.
89 Mimura S, Ando T, Ishiguro K, et al. Dipeptidyl peptidase-4 inhibitor anagliptin facilitates restoration of dextran sulfate sodium-induced colitis. Scand J Gastroenterol 2013;48:1152-9.

90 Yang Y, Cui X, Chen Y, et al. Exendin-4, an analogue of glucagon-like peptide-1, attenuates hyperalgesia through serotonergic pathways in rats with neonatal colonic sensitivity. J Physiol Pharmacol 2014;65:349-57.

91 Hellström PM, Hein J, Bytzer P, et al. Clinical trial: the glucagon-like peptide-1 analogue ROSE-010 for management of acute pain in patients with irritable bowel syndrome: a randomized, placebo-controlled, double-blind study. Aliment Pharmacol Ther 2009;29:198-206.

92 Everhart J. Digestive diseases and diabetes. In: Harris Ml, Cowie CC, Stern MP, et al, eds. Diabetes in America, 2nd edn:457-85.

93 Madsen KB, Askov-Hansen C, Naimi RM, et al. Acute effects of continuous infusions of glucagon-like peptide (GLP)-1, GLP-2 and the combination (GLP-1 $+\mathrm{GLP}-2$ ) on intestinal absorption in short bowel syndrome (SBS) patients. A placebo-controlled study. Regul Pept 2013;184:30-9.

94 Kunkel D, Basseri B, Low K, et al. Efficacy of the glucagon-like peptide-1 agonist exenatide in the treatment of short bowel syndrome. Neurogastroenterol Motil 2011;23:739-e328.

95 Jeppesen P, Hartmann B, Thulesen J, et al. Glucagon-like peptide 2 improves nutrient absorption and nutritional status in short-bowel patients with no colon. Gastroenterology 2001;120:806-15.

96 Drucker DJ, Yusta B. Physiology and pharmacology of the enteroendocrine hormone glucagon-like peptide-2. Annu Rev Physiol 2014;76:561-83.

97 Kissow H, Hartmann B, Holst JJ, et al. Glucagon-like peptide-1 as a treatment for chemotherapy-induced mucositis. Gut 2013;62:1724-33.

98 Chaudhuri A, Ghanim H, Vora M, et al. Exenatide exerts a potent antiinflammatory effect. J Clin Endocrinol Metab 2012:97:198-207.

99 Makdissi A, Ghanim $\mathrm{H}$, Vora $\mathrm{M}$, et al. Sitagliptin exerts an antinflammatory action. J Clin Endocrinol Metab 2012;97:3333-41.

100 Hogan AE, Tobin AM, Ahern T, et al. Glucagon-like peptide-1 (GLP-1) and the regulation of human invariant natural killer T cells: lessons from obesity, diabetes and psoriasis. Diabetologia 2011;54:2745-54.

101 Sun F, Yu K, Yang Z, et al. Impact of GLP-1 receptor agonists on major gastrointestinal disorders for type 2 diabetes mellitus: a mixed treatment comparison meta-analysis. Exp Diabetes Res 2012;2012:230624.

102 Gutzwiller J-P, Hruz P, Huber AR, et al. Glucagon-like peptide-1 is involved in sodium and water homeostasis in humans. Digestion 2006;73:142-50.

103 Wettergren A, Schjoldager B, Mortensen PE, et al. Truncated GLP-1 (proglucagon 78-107-amide) inhibits gastric and pancreatic functions in man. Dig Dis SCi 1993;38:665-73.

104 Franke A, Keller J, Holst JJ, et al. Effects of glucagon-like peptide-1 on human pancreatic enzyme secretion (Abstract). Digestion 1996;57:227.

105 Koehler JA, Baggio LL, Yusta B, et al. GLP-1R agonists promote normal and neoplastic intestinal growth through mechanisms requiring Fgf7. Cell Metab 2015;21:379-91.

106 Derogar M, Hull MA, Kant P, et al. Increased risk of colorectal cancer after obesity surgery. Ann Surg 2013;258:983-8.

107 Wettergren A, Wøjdemann M, Holst JJ. Glucagon-like peptide-1 inhibits gastropancreatic function by inhibiting central parasympathetic outflow. Am J Physiol 1998;275:G984-92.

108 Zhou J, Montrose-Rafizadeh C, Janczewski AM, et al. Glucagon-like peptide-1 does not mediate amylase release from AR42J cells. J Cell Physiol 1999;181:470-8.

109 Elashoff M, Matveyenko AV, Gier B, et al. Pancreatitis, pancreatic, and thyroid cancer with glucagon-like peptide-1-based therapies. Gastroenterology 2011:141:150-6.

110 Lando HM, Alattar M, Dua AP. Elevated amylase and lipase levels in patients using glucagonlike peptide-1 receptor agonists or dipeptidyl-peptidase-4 inhibitors in the outpatient setting. Endocr Pract 2012;18:472-7.

111 Tokuyama $\mathrm{H}$, Kawamura $\mathrm{H}$, Fujimoto $\mathrm{M}$, et al. A low-grade increase of serum pancreatic exocrine enzyme levels by dipeptidyl peptidase-4 inhibitor in patients with type 2 diabetes. Diabetes Res Clin Pract 2013;100:e66-9.

112 Nachnani JS, Bulchandani DG, Nookala A, et al. Biochemical and histological effects of exendin-4 (exenatide) on the rat pancreas. Diabetologia 2010;53:153-9.

113 Gier B, Matveyenko AV, Kirakossian D, et al. Chronic GLP-1 receptor activation by exendin-4 induces expansion of pancreatic duct glands in rats and accelerates formation of dysplastic lesions and chronic pancreatitis in the $\operatorname{Kras}(\mathrm{G} 12 \mathrm{D})$ mouse model. Diabetes 2012;61:1250-62.

114 Ellenbroek JH, Töns HAM, Westerouen van Meeteren MJA, et al. Glucagon-like peptide-1 receptor agonist treatment reduces beta cell mass in normoglycaemic mice. Diabetologia 2013;56:1980-6.

115 Matveyenko AV, Dry S, Cox HI, et al. Beneficial endocrine but adverse exocrine effects of sitagliptin in the human islet amyloid polypeptide transgenic rat model of type 2 diabetes: interactions with metformin. Diabetes 2009;58: 1604-15.

116 Aston-Mourney K, Subramanian SL, Zraika S, et al. One year of sitagliptin treatment protects against islet amyloid-associated $\beta$-cell loss and does not induce 
pancreatitis or pancreatic neoplasia in mice. Am J Physiol Endocrinol Metab 2013;305:E475-84.

117 Busch SJ, Hoffmann P, Sahota P, et al. Studies in rodents with the dipeptidyl peptidase-4 inhibitor vildagliptin to evaluate possible drug-induced pancreatic histological changes that are predictive of pancreatitis and cancer development in man. Diabetes Obes Metab 2013;15:72-6.

118 Forest T, Holder D, Smith A, et al. Characterization of the exocrine pancreas in the male zucker diabetic Fatty rat model of type 2 diabetes mellitus following 3 months of treatment with sitagliptin. Endocrinology 2014;155:783-92.

119 Gotfredsen CF, Mølck A-M, Thorup I, et al. The human GLP-1 analogs liraglutide and semaglutide: absence of histopathological effects on the pancreas in nonhuman primates. Diabetes 2014;63:2486-97.

120 Nyborg NCB, Mølck A-M, Madsen LW, et al. The human GLP-1 analog liraglutide and the pancreas: evidence for the absence of structural pancreatic changes in three species. Diabetes 2012:61:1243-9.

121 Tatarkiewicz K, Belanger P, Gu G, et al. No evidence of drug-induced pancreatitis in rats treated with exenatide for 13 weeks. Diabetes Obes Metab 2013;15:417-26.

122 Vrang N, Jelsing J, Simonsen $\mathrm{L}$, et al. The effects of 13 wk of liraglutide treatment on endocrine and exocrine pancreas in male and female ZDF rats: a quantitative and qualitative analysis revealing no evidence of drug-induced pancreatitis. Am J Physiol Endocrinol Metab 2012;303:E253-64.

123 Koehler JA, Baggio LL, Lamont BJ, et al. Glucagon-like peptide-1 receptor activation modulates pancreatitis-associated gene expression but does not modify the susceptibility to experimental pancreatitis in mice. Diabetes 2009;58:2148-61.

124 Tatarkiewicz K, Smith PA, Sablan EJ, et al. Exenatide does not evoke pancreatitis and attenuates chemically induced pancreatitis in normal and diabetic rodents. Am J Physiol Endocrinol Metab 2010;299:E1076-86.

125 Zhao H, Wang L, Wei R, et al. Activation of glucagon-like peptide-1 receptor inhibits tumourigenicity and metastasis of human pancreatic cancer cells via PI3K/ Akt pathway. Diabetes Obes Metab 2014;16:850-60.

126 Butler AE, Campbell-Thompson M, Gurlo T, et al. Marked expansion of exocrine and endocrine pancreas with incretin therapy in humans with increased exocrine pancreas dysplasia and the potential for glucagon-producing neuroendocrine tumors. Diabetes 2013;62:2595-604.

127 Bonner-Weir S, In't Veld PA, Weir GC. Reanalysis of study of pancreatic effects of incretin therapy: methodological deficiencies. Diabetes Obes Metab 2014; 16:661-6

128 Harja E, Lord J, Skyler JS. An analysis of characteristics of subjects examined for incretin effects on pancreatic pathology. Diabetes Technol Ther 2013;15:609-18.

129 Dore $\mathrm{DD}$, Bloomgren $\mathrm{GL}$, Wenten $\mathrm{M}$, et al. A cohort study of acute pancreatitis in relation to exenatide use. Diabetes Obes Metab 2011;13:559-66.

130 Funch D, Gydesen H, Tornøe K, et al. A prospective, claims-based assessment of the risk of pancreatitis and pancreatic cancer with liraglutide compared to other antidiabetic drugs. Diabetes Obes Metab 2014;16:273-5.

131 Garg R, Chen W, Pendergrass M. Acute pancreatitis in type 2 diabetes treated with exenatide or sitagliptin: a retrospective observational pharmacy claims analysis. Diabetes Care 2010;33:2349-54.

132 Giorda CB, Picariello R, Nada E, et al. Incretin therapies and risk of hospital admission for acute pancreatitis in an unselected population of European patients with type 2 diabetes: a case-control study. Lancet Diabetes Endocrinol 2014:2:111-15.

133 Li L, Shen J, Bala MM, et al. Incretin treatment and risk of pancreatitis in patients with type 2 diabetes mellitus: systematic review and meta-analysis of randomised and non-randomised studies. BMJ 2014;348:g2366.

134 Wenten M, Gaebler JA, Hussein M, et al. Relative risk of acute pancreatitis in initiators of exenatide twice daily compared with other anti-diabetic medication: a follow-up study. Diabet Med 2012;29:1412-18.

135 Singh S, Chang H-Y, Richards TM, et al. Glucagonlike peptide 1-based therapies and risk of hospitalization for acute pancreatitis in type 2 diabetes mellitus: a population-based matched case-control study. JAMA Intern Med 2013;173: 534-9.

136 Raz I, Bhatt DL, Hirshberg B, et al. Incidence of pancreatitis and pancreatic cancer in a randomized controlled multicenter trial (SAVOR-TIMI 53) of the dipeptidyl peptidase-4 (DPP-4) inhibitor saxagliptin. Diabetes Care 2014;37:2435-41.

137 White W, Cannon C, Heller SR. Alogliptin after acute coronary syndrome in patients with type 2 diabetes. N Engl J Med 2013;369:1327-35.

138 Green JB, Bethel MA, Armstrong PW, et al. Effect of sitagliptin on cardiovascular outcomes in type 2 diabetes. N Engl J Med 2015;373:232-42.

139 Pfeffer MA, Claggett B, Diaz R, et al. Lixisenatide in patients with type 2 diabetes and acute coronary syndrome. N Engl J Med 2015;373:2247-57.

140 Meier JJ, Nauck MA. Risk of pancreatitis in patients treated with incretin-based therapies. Diabetologia 2014;57:1320-4.

141 Egan $A G$, Blind $E$, Dunder $K$, et al. Pancreatic safety of incretin-based drugs-FDA and EMA assessment. N Engl J Med 2014;370:794-7.
142 Dardevet D, Moore MC, Neal D, et al. Insulin-independent effects of GLP-1 on canine liver glucose metabolism: duration of infusion and involvement of hepatoportal region. Am J Physiol Endocrinol Metab 2004;287:E75-81.

143 Seghieri M, Rebelos E, Gastaldelli A, et al. Direct effect of GLP-1 infusion on endogenous glucose production in humans. Diabetologia 2013;56:156-61.

144 Panjwani N, Mulvihill EE, Longuet C, et al. GLP-1 receptor activation indirectly reduces hepatic lipid accumulation but does not attenuate development of atherosclerosis in diabetic male ApoE(-/-) mice. Endocrinology 2013;154:127-39.

145 Parlevliet ET, Wang Y, Geerling JJ, et al. GLP-1 receptor activation inhibits VLDL production and reverses hepatic steatosis by decreasing hepatic lipogenesis in high-fat-fed APOE*3-Leiden mice. PLOS ONE 2012;7:e49152.

146 Ben-Shlomo S, Zvibel I, Rabinowich L, et al. Dipeptidyl peptidase 4-deficient rats have improved bile secretory function in high fat diet-induced steatosis. Dig Dis $\mathrm{SCi}$ 2013;58:172-8.

147 Marzioni M, Alpini G, Saccomanno S, et al. Exendin-4, a glucagon-like peptide receptor agonist, protects cholangiocytes from apoptosis. Gut 2009;58:990-7.

148 Liu Y, Wei R, Hong T-P. Potential roles of glucagon-like peptide-1-based therapies in treating non-alcoholic fatty liver disease. World I Gastroenterol 2014:20:9090-7.

149 Iwasaki T, Yoneda M, Inamori M, et al. Sitagliptin as a novel treatment agent for non-alcoholic Fatty liver disease patients with type 2 diabetes mellitus. Hepatogastroenterology 2011;58:2103-5.

150 Ohki T, Isogawa A, Iwamoto $M$, et al. The effectiveness of liraglutide in nonalcoholic fatty liver disease patients with type 2 diabetes mellitus compared to sitagliptin and pioglitazone. Sci World J 2012;2012:1-8.

151 Eguchi $Y$, Kitajima $Y$, Hyogo $\mathrm{H}$, et al. Pilot study of liraglutide effects in non-alcoholic steatohepatitis and non-alcoholic fatty liver disease with glucose intolerance in Japanese patients (LEAN-J). Hepatol Res 2015:45:269-78.

152 Cuthbertson DJ, Irwin A, Gardner CJ, et al. Improved glycaemia correlates with liver fat reduction in obese, type 2 diabetes, patients given Glucagon-Like Peptide-1 (GLP-1) receptor agonists. PLoS ONE 2012;7:e50117.

153 Yilmaz Y, Yonal O, Deyneli O, et al. Effects of sitagliptin in diabetic patients with nonalcoholic steatohepatitis. Acta Gastroenterol Belg 2012;75:240-4.

154 Tang A, Rabasa-Lhoret R, Castel H, et al. Effects of insulin glargine and liraglutide therapy on liver fat as measured by magnetic resonance in patients with type 2 diabetes: a randomized trial. Diabetes Care 2015;38:1339-46.

155 Kato H, Nagai Y, Ohta A, et al. Effect of sitagliptin on intrahepatic lipid content and body fat in patients with type 2 diabetes. Diabetes Res Clin Pract 2015;109:199-205.

156 Armstrong MJ, Gaunt P, Aithal GP, et al. Liraglutide safety and efficacy in patients with non-alcoholic steatohepatitis (LEAN): a multicentre, double-blind, randomised, placebo-controlled phase 2 study. Lancet 2015. Published Online First: 19 Nov 2015. doi: 10.1016/S0140-6736(15)00803-X

157 Day CP, James OF. Steatohepatitis: a tale of two 'hits'? Gastroenterology 1998; 114:842-5

158 Tilg $\mathrm{H}$, Moschen AR. Evolution of inflammation in nonalcoholic fatty liver disease: the multiple parallel hits hypothesis. Hepatology 2010;52:1836-46.

159 Souza-Mello V, Gregório BM, Cardoso-de-Lemos FS, et al. Comparative effects of telmisartan, sitagliptin and metformin alone or in combination on obesity, insulin resistance, and liver and pancreas remodelling in C57BL/6 mice fed on a very high-fat diet. Clin Sci 2010;119:239-50.

160 Maiztegui B, Borelli MI, Madrid VG, et al. Sitagliptin prevents the development of metabolic and hormonal disturbances, increased $\beta$-cell apoptosis and liver steatosis induced by a fructose-rich diet in normal rats. Clin Sci 2011;120:73-80.

161 Shirakawa J, Fujii $\mathrm{H}$, Ohnuma K, et al. Diet-induced adipose tissue inflammation and liver steatosis are prevented by DPP-4 inhibition in diabetic mice. Diabetes 2011:60:1246-57.

162 Svegliati-Baroni G, Saccomanno S, Rychlicki C, et al. Glucagon-like peptide-1 receptor activation stimulates hepatic lipid oxidation and restores hepatic signalling alteration induced by a high-fat diet in nonalcoholic steatohepatitis. Liver Int 2011:31:1285-97.

163 Sharma S, Mells JE, Fu PP, et al. GLP-1 analogs reduce hepatocyte steatosis and improve survival by enhancing the unfolded protein response and promoting macroautophagy. PLOS ONE 2011;6:e25269.

164 Jung Y-A, Choi Y-K, Jung G-S, et al. Sitagliptin attenuates methionine/choline-deficient diet-induced steatohepatitis. Diabetes Res Clin Pract 2014;105:47-57.

165 Klein T, Fujii M, Sandel J, et al. Linagliptin alleviates hepatic steatosis and inflammation in a mouse model of non-alcoholic steatohepatitis. Med Mol Morphol 2014;47:137-49.

166 Novo Nordisk. Liraglutide 3.0 mg for Weight Management (NDA 206-321). Briefing Document. Endocrinologic and Metabolic Drug Advisory Committee. 2014.

167 Bytzer $\mathrm{P}$, Talley NJ, Leemon M, et al. Prevalence of gastrointestinal symptoms associated with diabetes mellitus. Arch Intern Med 2001:161:1989.

168 Beuers U, Göke B. GLP-1 analogues: a new therapeutic approach to prevent ductopenia in cholangiopathies? Gut 2009;58:902-3. 